\title{
GEOPHYSICAL INVESTIGATIONS IN THE OLD PANAMA ARCHAEOLOGICAL SITE
}

\author{
Alexis Mojica ${ }^{1,3 *}$, Leomar Acosta², Roger Guérin ${ }^{3}$, Carlos A. Ho ${ }^{4}$ \& \\ Orlando Caballero 5
}

\author{
${ }^{1}$ Estación RN 50, Universidad de Panamá \\ ${ }^{2}$ Laboratoire de Physisque des Solides, Université Paris - Sud, France \\ ${ }^{3}$ Département de Géophysique Appliquée, Université Pierre et Marie Curie, France \\ ${ }^{4}$ Universidad Tecnológica de Panamá, Centro Experimental de Ingeniería. \\ ${ }^{5}$ Ministerio de Educación, Corozal, Cárdenas. \\ *Autor para contacto: amojica@ancon.up.ac.pa
}

(Recibido: 14/11/07; aceptado: 11/01/07)

\begin{abstract}
The results of geophysical prospections in an archaeological site of hispanic type in Panama (Central America) are presented in this article. The archaeological site of Old Panama has been intensively investigated with the objective to know the space - time organization of man in the past. A magnetic prospection was developed in the central sector of the site; the rank of magnitude of the magnetic anomalies allowed the identification of certain characteristics of hispanic type and in addition, the presence of metallic devices, typical of more recent occupation times. On the other hand, the results of three electrical tomographies are presented. From these results it was possible to identify the depth of the metallic objects detected by magnetic prospection.

Key words: Magnetic prospection, electrical prospection, apparent resistivity, electrical anomaly, magnetic anomaly, electrical tomography, Old Panama archaeological site.

RESUMEN: En este artículo se presentan los resultados de una prospección geofísica en un sitio arqueológico de tipo hispánico en Panamá (América Central). Este lugar, conocido como sitio arqueológico de Panamá Viejo, ha sido objeto de intensivas investigaciones con el objetivo de conocer la organización espacio-temporal de su ocupación. Una prospección magnética fue desarrollada en el sector central del sitio. Los rangos de magnitud de las anomalías magnéticas facilitaron la identificación de ciertos rasgos de tipo hispánico y además, la presencia de artefactos metálicos propios de una época de ocupación más reciente. Por otro lado, se presentan los resultados de tres tomografías eléctricas. Con dichos resultados se logró identificar la profundidad de los objetos metálicos detectados en la prospección magnética.

Palabras clave: Prospección magnética, prospección eléctrica, resistividad aparente, anomalía eléctrica, anomalía magnética, tomografía eléctrica, sitio arqueológico de Panamá Viejo.
\end{abstract}




\section{INTRODUCTION}

In the last 50 years, the methods of geophysical prospection have played a significant role in the detection of buried archaeological remains. Today, the magnetic and electrical methods are the most used in archaeology (Hesse et al., 1986; Tabbagh, 1992; Dabas et al., 1998). Nevertheless, other geophysical methods like the electromagnetic ones, have shown very satisfactory results (Imai et al., 1987; Scollar et al., 1990; Sambuelli et al., 1999; Persson \& Olofsson, 2004; Evangelista $\&$ Wedepohl, 2004).

The application of these methods in certain archaeological sites has been of great interest for some authors (e.g. Pipan et al., 1999; Bossuet et al., 2001). Panama has numerous archaeological sites that have been object of later occupations; among them and one of the most important is the archaeological site of Old Panama. This site has numerous buildings (churches, governmental and commerce centers, etc.) constructed by the Europeans during the $16^{\text {th }}$ century. However, this site was occupied by people during the last century for the development of military activities. The techniques of magnetic and electrical prospection were applied with the aim to getting knowledge of the buried archaeological characteristics (typical of the time of the Spanish conquest) and metallic devices in the central zone of this site (product of the military occupation). Firstly, a specific process of cartography, filtering and treatments, was made on the magnetic data, whereas for the second, a process of inversion of pseudo - section to obtain electrical tomographies throughout 3 profiles, was developed.

\section{THE SITE}

The archaeological site (UTM 666476, 995810) is located in the peripheries of the metropolitan area of Panama city. Figure 1 shows the location of the central zone of this site in the map of Panama. The zone of interest is represented by the gray rectangle $(48 \mathrm{~m} \times 50 \mathrm{~m})$ where the magnetic prospection was developed. Within this zone, 3 profiles for electrical prospection were developed (AA', BB' and CC'), the first two having a length of $20 \mathrm{~m}$, and $30 \mathrm{~m}$ the third one. This zone is characterized by the presence of outcrops of andesitic agglomerate, belonging to the volcanic member of the Panama Formation (TM - PA). The rest of the zone is made up of alluvial material composed by clasts of tufas and basalts, and sandy clays.

A project of restoration and conservation of the site is being developed by the Patronato Panamá Viejo, whose results reported by Rovira, (2002) and Martín-Rincón (2003) have revealed the existence of an urban plan that corroborates the historical information regarding to the construction of the site. However, the methods of geophysical prospection can play an important role in its detection and parameterisation, optimizing economic resources and time.

\section{GEOPHYSICAL METHODS}

In order to get a better knowledge on the Hispanic occupation during the last century in this zone, two geophysical methods were used: magnetic and electrical.

\section{Magnetic}

For this investigation, a caesium vapor magnetometer type G-858 was used with a sensitivity of $0.01 \mathrm{nT}$. With the idea to measure the vertical magnetic gradient in different points on the zone of interest, two sensors separated a distance $1 \mathrm{~m}$ on a system of aluminum tubes for the easy handling on the land, were used (Fig. 2). The difference between the values of the total magnetic field measured by both sensors can be considered as a good approach to the magnetic gradient (Bossuet et al., 2001). The important characteristic of this modality is that the transitory magnetic variations are removed and the effect of the regional magnetic anomaly is completely filtered, registering only those anomalies that are bound to structures located near the surface.

The registration of the magnetic gradient is recorded automatically throughout several parallel profiles that define the zone of interest. This is made by the use of a console connected to both sensors. For our case, 48 profiles of 50 


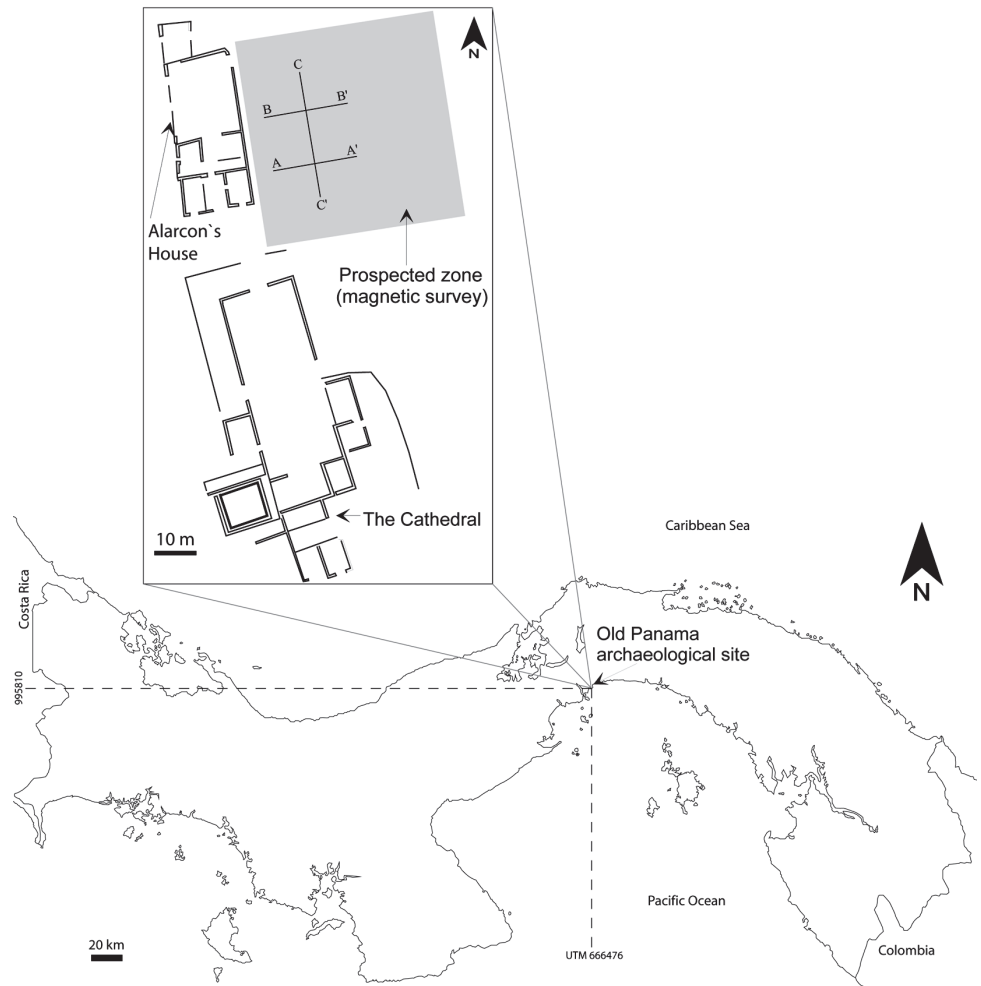

Fig. 1: Location of the archaeological site of Old Panama and the zone of interest.

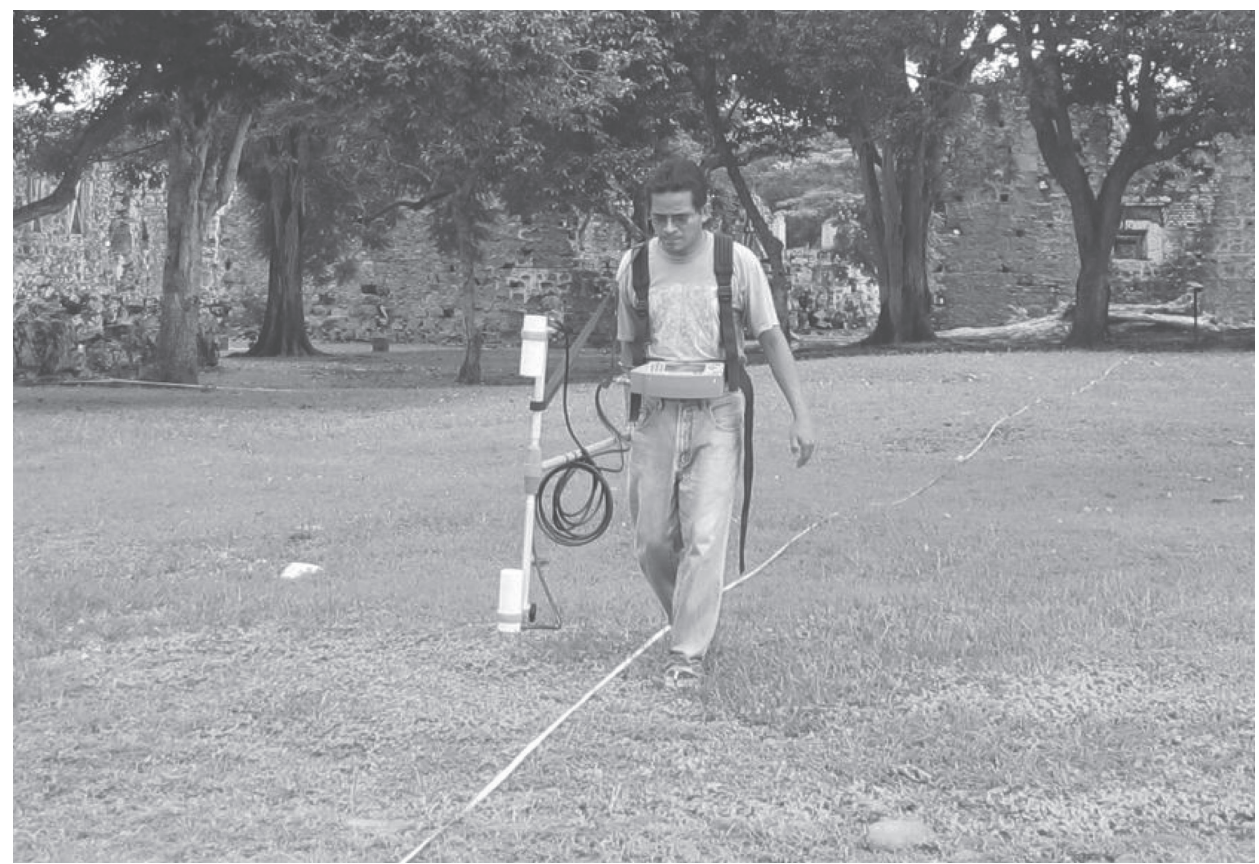

Fig. 2: Caesium magnetometer system (G-858 of Geometrics) in gradiometer mode. 


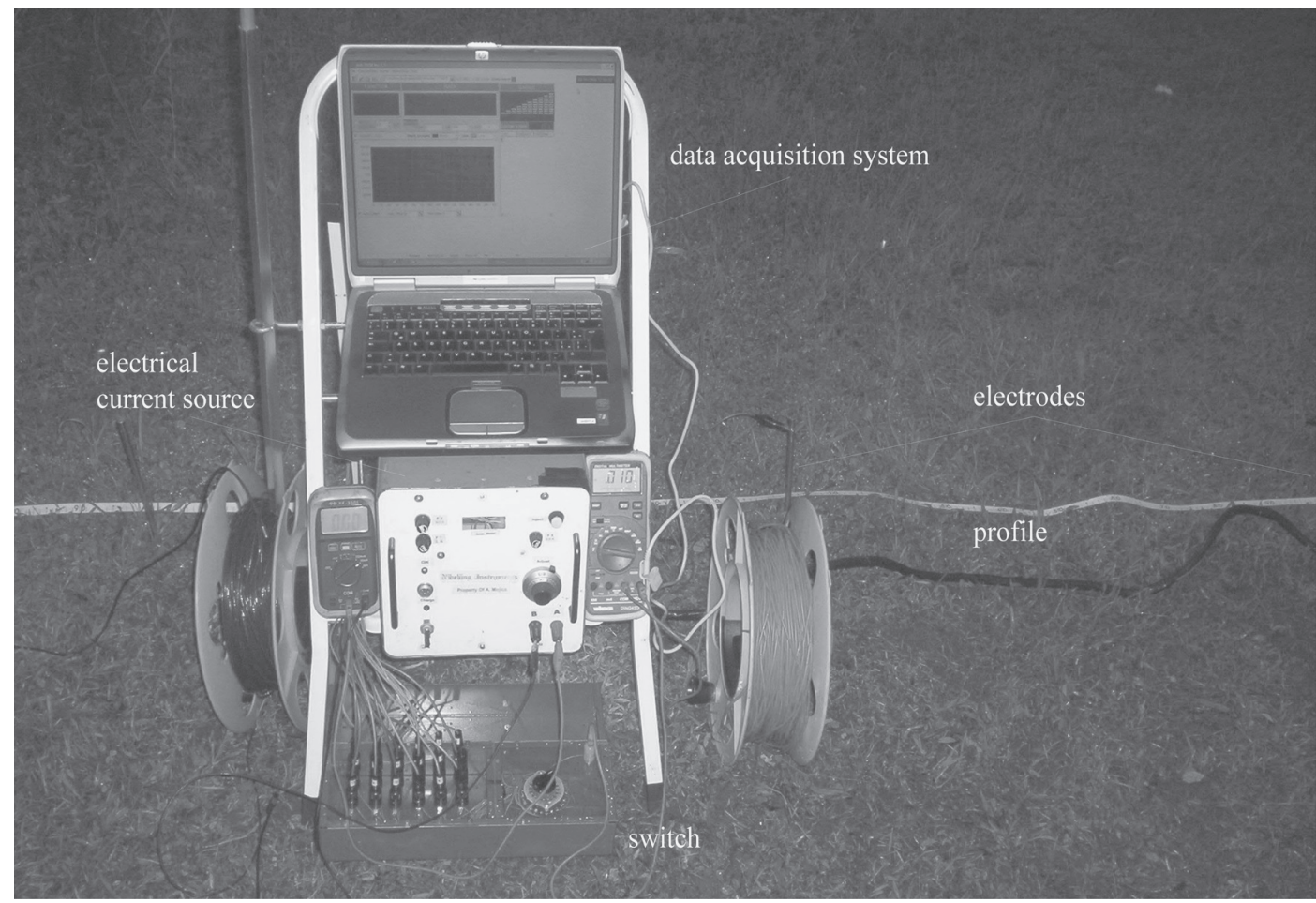

Fig. 3: Multi-electrode system used for 2- dimensional resistivity survey.

$\mathrm{m}$ of length at a distance of $1 \mathrm{~m}$ were defined, in direction NW-SE (gray rectangle, figure 1). With the idea to obtain a map of the space variations of the vertical magnetic gradient, the data were put under specific treatments of saturation and application of certain filters.

\section{Resistivity tomography}

This modality corresponds to an active method of prospection used for the generation of images of the subsoil model in terms of electrical resistivity. The method was applied to each one of the profiles of figure 1. A multielectrode system connected to a switch and a source of electric current were used (with a primary feeding and an output voltage of $\pm 12 \mathrm{~V}$ and $300 \mathrm{VAC}$, respectively). For profiles $\mathrm{AA}^{\prime}$ and $\mathrm{BB}$ ', 21 electrodes were used, whereas for profile $\mathrm{CC}^{\prime}$ a total of 31 electrodes were used. Due to the low

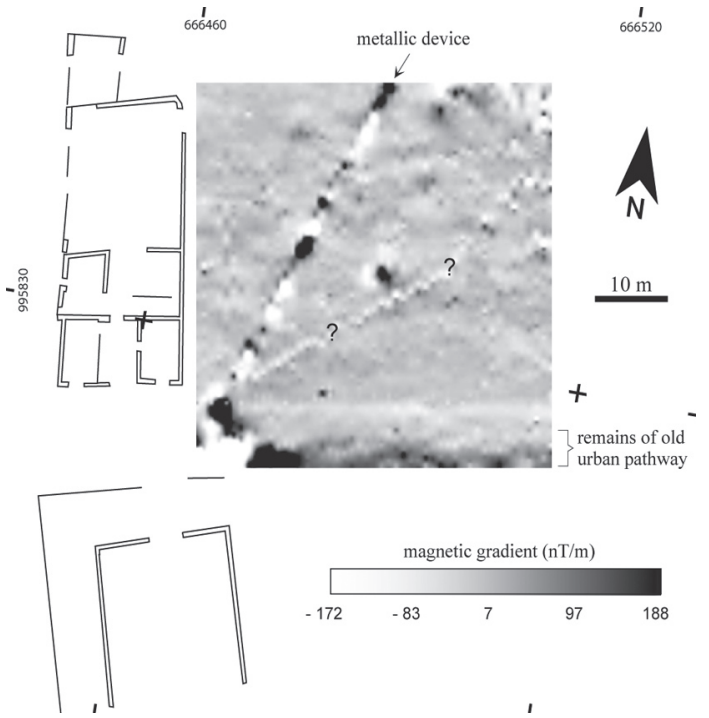

Fig. 4: Superposition of the map of the vertical magnetic gradient and the archaeological ruins of the central zone of the archaeological site of Old Panama. 


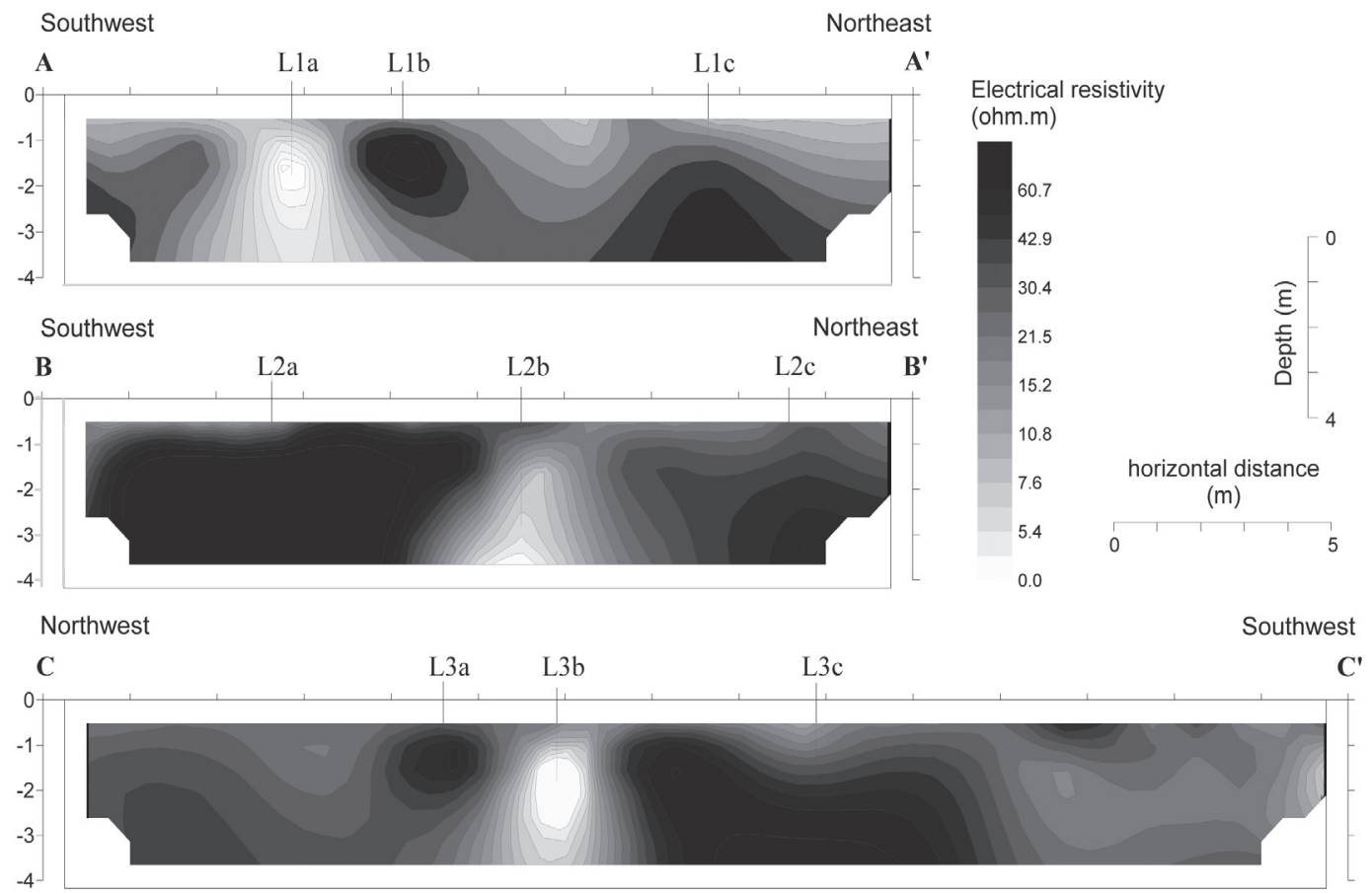

Fig. 5: Electrical tomographies (pole-pole array) carried out perpendicular to the ruins of the Alarcón House (AA' and BB') and parallel to it (CC').

level of noise in the area, a pole-pole electrodical arrangement was used (Fig. 3).

The data registered and stored automatically on the land were put under a process of inversion by the use of Res2Dinv, which is based on the smoothness - constrained least squares method (Loke \& Barker, 1996). This process includes the calculation of the values of apparent resistivity and the application of a nonlinear technique of optimization of square minimums (deGroot-Hedlin \& Constable, 1990; Loke \& Barker, 1996). Certain authors have previously developed some inversion treatments to apply them to the archaeological prospection (Noel \& Xu, 1991).

\section{FIELD RESULTS AND DISCUSSIONS}

After putting the data of the vertical magnetic gradient under the previously mentioned processes, an scale image on grays of figure 4 was obtained. With the objective to complete the interpretation of the magnetic data, a single level of saturation was used. The image reveals strong variations of the vertical magnetic gradient; of this result, only about of $27 \%$ of the recorded values is related to the range between +10 and $-10 \mathrm{nT} /$ $\mathrm{m}$. The nature of the image reveals the existence of magnetic anomalies related to two periods of occupation: Hispanic and the one of the last century. For the first, a magnetic anomaly in the south part of the image can be observed, that could be possibly associated to one of the main streets that communicated the central sector of the city with the constructions located in the eastern part of the site. This fact corroborates the information provided by Martín-Rincón (2003) on the disposition of the urban plan of the old city of Panama.

On the other hand, the existence of a strong anomaly lined up with direction NE-SW, suggests the presence of a shallow magnetic device which could be closely related to a system of water drainage constructed of metallic tubes for 


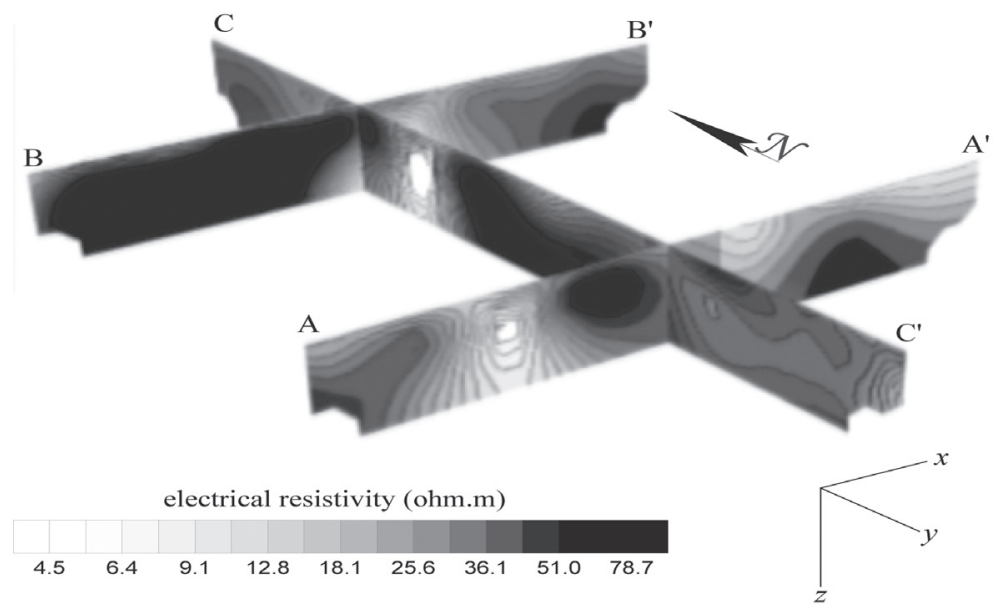

Fig 6: 3-dimensional representation of the electrical tomography obtained in the central sector of the archaeological site of Old Panama.

the supplying of the stables during the military occupation during the last century. In this same context, another alignment with less magnetic variations in relation to the ones described above is also observed.

The results obtained by the inversion process of the 3 pseudo-sections of apparent resistivity are shown in figure 5 .

The southwest part of profile AA' displays very low values of electrical resistivity $(<5$ ohm.m) while in the northeast, the high values are predominant ( $>50 \mathrm{ohm} . \mathrm{m})$. Profile BB' displays high values of apparent resistivity both in the northeast part and the southwest part (> 50 ohm.m). Nevertheless, these values become predominant in the southwest part. In this same profile, a zone with low values (similar to profile AA') of apparent resistivity appears. For profile CC', very low values of apparent resistivity $(<5 \mathrm{ohm} . \mathrm{m})$ are observed in the central part, while in the northeast and southeast zone high values (> 50 ohm.m) predominate.

In these three profiles, the characteristics of the very low electrical resistivity located in L1a, $\mathrm{L} 2 \mathrm{~b}$ and L3b, presents approximately the same depth $(\sim 2.0 \mathrm{~m})$. On the other hand, the characteristics of high values of apparent resistivity located in the L1b, L1c, L2a, L2c, L3a and L3c positions, have variable depths.
Figure 6 shows the resistant and conductive characteristics of the three profiles arranged in a perpendicular way for a 3-dimensional view.

The characteristics corresponding to the positions L1a, L2b and L3b seem to be associated to the system of drainage, previously described, whereas the characteristics L1b, L1c, L2a, L2c, L3a and $\mathrm{L} 3 \mathrm{c}$ are associated to volcanic rocks of the site. The superficial layers that present intermediate values of apparent resistivity (10-45 ohm.m) are associated to the alluvial material of the site.

\section{CONCLUSIONS}

We have confirmed that geophysical surveying methods are useful tools to support archaeological investigations. These methods are faster, non invasive and less expensive than excavations. The archaeological site of Old Panama was the scene of two periods of occupation: the arrival and the establishment of the Europeans in the $16^{\text {th }}$ century and the military presence during the last century. The use of magnetic techniques allowed the identification of metallic devices characteristic of the time of military occupation and routes of the Hispanic time. In this same context, the use of electrical techniques allowed the location at depth, of geological features and some characteristics revealed in the magnetic prospection. 


\section{ACKNOWLEDGMENTS}

We are infinitely thankful to Sigfrido Beluche (Laboratory of Electronic Instrumentation, University of Panama) for his important support in the assembly of the alternating current prototype; to Patronato Panamá Viejo and D. Delgado by their field support. We are thankful to Hilda Olave for grammar revision of the text.

\section{REFERENCES}

BOSSUET, G., CAMERLYNCK, C., BREHONNET, C. \& PETIT, C., 2001: Magnetic prospecting of diachronic structures (antiquity to First World War) on the site of the Sanctuary of Ribemont - sur Ancre (Somme, France).- Archaeol. Prosp. 8: $67-77$.

DABAS, M., DELÉTANG, H., FERDIÈRE, A., JUNG, C. \& ZIMMERMANN, W. H., 1998: La prospection - Col. Archaeol.223 p. Errance, France.

deGROOT-HEDLIN, C. \& CONSTABLE, S., 1990: Occam's inversion to generate smooth, two - dimensional models from magnetotelluric data.- Geoph. 55: 1613 - 1624.

EVANGELISTA, R. \& WEDEPOHL, E., 2004: Archaeological geophysics: 3D imaging of the Muweilah archaeological site, United Arab Emirates.- Explor. Geoph. 35: 93 - 98.

HESSE, A., JOLIVET, A. \& TABBAGH, A., 1986: New prospects in shallow depth electrical surveying for archaeological and pedological applications.- Geophysics, 51: 585 - 594.

IMAI, T., SAKAYAMA, T., \& KANEMORI, T., 1987: Use of ground - probing radar and resistivity surveys for archaeological investigations.- Geophysics, 52: $137-150$.
LOKE, M.H., \& BARKER, R., 1996: Rapid, least - squares inversion of apparent resistivity pseudosections by a quasi - Newton method.- Geophys. Prospect. 44: $131-152$.

MARTÍN-RINCÓN, J., 2003: Panamá La Vieja: la recuperación de su traza urbana.- Rev. Arqueol. Amer. 22: 165 - 183.

NOEL, M. \& XU, B., 1991: Archaeological investigation by electrical resistivity tomography: a preliminary study.- Geophys. J. Int. 107: 95 - 102.

PERSSON, K. \& OLOFSSON, B., 2004: Inside a mound: Applied geophysics in archaeological prospecting at the Kings' Mounds, Gamla Upssala, Sweden.- J. Archaeol. Sc. 31: 551 - 562 .

PIPAN, M., BARADELLO, L., FORTE, E., PRIZZON, A. \& FINETTI, I., 1999: 2 - D and $3-\mathrm{D}$ processing and interpretation of multi - fold ground penetrating radar data: a case history from an archaeological site.J. App. Geoph. 41: 271 - 292.

ROVIRA, B., 2002: El proyecto arqueológico Panamá La Vieja: balance de un quinquenio.- Arqueología de Panamá La Vieja - Avances de investigación, 1: 1- 18.

SAMBUELLI, L., SOCCO, L. \& BRECCIAROLI, L., 1999: Acquisition and processing of electric, magnetic and GPR data on a Roman site (Victimulae, Salussola, Biella).J. Appl. Geophys. 41: 189- 204.

SCOLLAR, I., TABBAGH, A., HESSE, A. \& HERZOG, I., 1990: Archaeological prospecting and remote sensing. - 674 p. Cambridge University Press, United Kingdom.

TABBAGH, A., 1992: Méthodes géophysiques appliquées à la prospection archéologique.- Mém. Soc. géol. France, 161: 9 - 15. 
